\title{
Planerad och iscensatt fotojournalistik
}

\author{
AF JENS E. KJELDSEN OCH GUNNAR NYGREN
}

\section{Abstract}

Ijanuari valåret 2010 publicerade Svenska Dagbladet en gruppbild av alla åtta partiledare. Bilden är ett exempel på planerad fotojournalistik, men också ett exempel på hur bilders betydelse kan förändras och ges nya tolkningar jämfört med den ursprungliga avsikten. Artikeln analyserar arbetsprocessen bakom bilden utifrån observationer och intervjuer, dess iscensättning och relation till bildjournalistikens normer och traditioner. Det utgår från teorier om pseudohändelser och ikoniska bilder, och analyserar fotografiets estetiska och retoriska kvalitéer. Resultatet visar att processen bakom bilden inrymmer en rad ambivalenser $i$ bildjournalisternas självförståelse och syn på pressfotografi. Det visar också att den process som skapar ikoniska bilder är komplicerad och oförutsägbar. Mediernas representationer av politiker kan planeras, men också omtolkas i mötet med publiken.

De senaste 20 åren har bildjournalistiken blivit alltmer central i de svenska morgontidningarna, samtidigt som hela det redaktionella innehållet blivit mer planerat. Trots detta vet vi ganska lite om planerad fotojournalistik - ja, arbetsprocesser på bildredaktioner och även fotojournalistik i stort är överraskande outforskat. Denna text utgör ett litet steg på vägen mot att avhjälpa denna brist genom att undersöka arbetsprocessen för planerad fotojournalistik. Vi kommer att undersöka en konkret produkt av denna process vid bildredaktionen på Svenska Dagbladet: den 
så kallade "soffabilden". Vi visar hur detta fotografi är resultatet av en pseudohändelse som var skapad och iscensatt av Svenska Dagbladet i samarbete med de politiska partierna. Vi visar också hur denna pseudohändelse samtidigt iscensätter sig själv och tar vägar som inte var planerade.

Första delen tar teoretisk utgångspunkt i Daniel Boorstins teori om pseudohändelser, som han beskriver i boken The Image. Här beskriver vi planerad journalistik generellt och ger en konkret inblick i arbetsprocessen och tillblivelsen av "soffbilden" som fotografen Yvonne Åsell tog för Svenska Dagbladet i början av 2010. Med utgångspunkt i kvalitativa intervjuer och observationer på SvDs bildredaktion ger denna del en konkret empirisk insikt i hur planeringen och produktionen av ett planerat pressfotografi sker.

Andra delen undersöker hur bilden inramas och iscensätts av tidningen samt redogör för bildens utbredning. Centralt här är hur tidningen genom att beskriva fotografiet som ikoniskt och genom att skriva bildens historia, bidrar till att konstituera fotografiets betydelse och sin egen position som ceremonimästare vid viktiga händelser. Det blir också tydligt att iscensättningen innehåller en ambivalens mellan representationer av politiker som privatpersoner och deras officiella roller som partiledare.

Tredje delen analyserar fotografiets retoriska och estetiska kvalitéer i ljuset av teorier om ikonisk pressfotografi. Denna del understryker iscensättningen av bilden som ikonisk. Med hjälp av våra forskningsintervjuer pekar den på ännu en ambivalens, nämligen i journalisternas värdering av bildens karaktär och värde.

Fjärde delen är en kort avslutning som uppsummerar produktionen, iscensättningen och det fotografiska uttrycket samt de ambivalenser som historien om soffbilden rymmer. Det gäller spänningar i bildjournalisternas självförståelse och syn på pressfotografi och mediernas mångfacetterade representation av politik och politiker. Samt en diskussion om ikoniska bilder, pseudohändelser och mediernas gestaltning av politik. 


\section{Bildjournalistik som planerad produktion}

Bildjournalistiken har utvecklats och förändrats på många sätt de senaste 20-25 åren. På 1990-talet utvecklade många tidningar sin bildpolicy och bildens roll i tidningen uppvärderades. Den tekniska bakgrunden var övergången till offsettryck som skedde på 1980-talet, och som gjorde det billigare och snabbare att producera bilder (Hultén 1990). Många redaktioner inrättade fler bildredaktörer, tidningar fick ny design för att förstärka den visuella profilen (Edwardsson m fl 1994, Becker 1996).

De första åren på 2000-talet gick nästan alla morgontidningar över från broadsheet till tabloidformat. Detta innebar ytterligare ett steg mot mer visuella tidningar, texterna blev kortare och bildernas andel av det redaktionella innehållet ökade med omkring 20 procent i många tidningar (Sternvik 2007). Tabloidiseringen innebar också krav på en mer planerad produktion, fler sidor skulle produceras, samtidigt som redaktionerna krymptes. Antalet journalister i dagspressen har minskat med 20-25 procent sedan slutet av 1980-talet, och på storstadstidningarna är minskningen ännu större, flera redaktioner har till och med halverats (Asp m fl 2007, Sjöström 2011). För att klara produktionen av både nyhetstidningen och ett växande antal bilagor har redaktionella system utvecklats med en större grad av formatering av sidor i förväg. Innehållet planeras mer, textlängder och bildstorlekar bestäms i förväg (Nygren 2008).

Utvecklingen mot en mer planerad journalistik har påskyndats av nätjournalistiken. Tidningarnas webbsidor tar hand om de snabba nyheterna och utvecklar interaktiviteten med läsarna. Samtidigt som papperstidningen utvecklas mot att ge mer av fördjupning och bakgrund. Skillnaderna ökar mellan nät och papper (Nygren \& Zuiderveld 2011). Redaktionschefen på Svenska Dagbladet Martin Jönsson uttrycker förändringen av papperstidningen så här i samband med att tidningens nätutgåva nylanserades i mars 2011:

På motsvarande sätt förstärker vi papperstidningens styrkor. Det var länge sedan huvudfokus låg på att rapportera gårdagens nyheter: istället handlar det om att etablera dagens samtalsämnen, sätta nyhetsagendan, ge sammanhang, blicka framåt och utnyttja 
kraften i bildjournalistiken och den fördjupande nyhetsgrafiken. Nätets nerv matchas av papprets läsupplevelser, berättelser och överskådlighet (SvD 20110320).

För att klara dessa krav på papperstidningen måste innehållet $\mathrm{i}$ sin helhet planeras på ett helt annat sätt än i den gamla papperstidningen som byggde på gårdagens nyheter. Detta gäller också bildjournalistiken som blir central - både i den visuella papperstidningen och på nätet med dess nya gestaltningar som bildspel och rörliga bilder i olika former.

\section{Planerade nyheter}

Denne planering av produktionen av nyheter och bildjournalistik betyder inte nödvändigtvis att journalister konstruerar sina egna nyheter. Det handlar istället om en planering av hur händelser ska organiseras och förmedlas som nyheter. Det är tidningarnas uppgift att bevaka nyheter, inte att skapa dem. Samtidigt är många nyheter inte bara något som sker, utan något som skapas. Med professionaliseringen av politisk kommunikation och spin-doktorers inträde i politiken har det blivit vanligt för politiker och partier att organisera händelser och photo-opportunities som kan bevakas som nyheter. Sådana icke-händelser, som bara är skapade för att bli förmedlade i medierna och därför inte egentligen är nyheter kallar Daniel Boorstin for pseudohändelser. En pseudohändelse kan vare arrangerade tillfällen, men också presskonferenser, pressemeddelanden och till och med intervjuer om de inte är baserade på en händelse som är en nyhet som rapporteras. Som journalistisk genre är intervjun en pseudohändelse, eftersom den skapar en händelse mer än den täcker en nyhet. En pseudo-händelse, skriver Boorstin (1992: 20) karaktäriseras av att:

1. Den är inte spontan, men uppträder för att någon har planerat, planterat eller framkallat den.

2. Den är primärt planterad eller framkallad för att bli rapporterad. Därför arrangeras den för mediernas bekvämlighet, och framgången mäts utifrån hur mycket uppmärksamhet den får. 
3. Förhållandet till den underliggande verkligheten är oklart. Och det är denna oklarhet som gör den intressant. Nyheten om en tågolycka är vad som hände och konsekvenserna av detta. Men det intressanta vid en intervju är alltid i en viss mening om det verkligen har skett och vad som kan ha varit motiven.

4. Den har ofta till syfte att vara en självuppfyllande profetia. När ett hotell bjuder in medierna för att fira sin 50-årsdag som en viktig institution i staden, så etablerar man samtidigt detta faktum.

Boorstin framhåller att en ökande del av det vi läser, ser och hör i medierna från mitten av 1900-talet bestått av pseudohändelser. En fullständig beskrivning av pseudohändelser skulle inte vara mindre än det moderna Amerikas historia, hävdare han. Det har betydelse för journalistiken, för ju fler pseudohändelser vi utsätts för, desto större blir skillnaden mellan "hard news" och "soft news" (jf Boorstin 1992: 30).

I Boorstins beskrivning är pseudohändelser något som organisationer, företag och politiker iscensätter för att få mediernas uppmärksamhet och för att bli omtalade. Därför utforskar studier som undersöker pseudohändelser normalt hur pressen lockas till att bevaka saker som inte är spontana, men däremot är planerade enbart för att få nyhetsbevakning. Med nyhetsmediernas förändring från att vara nyhetsinsamlade till att vara nyhetskonstruerade upplever vi emellertid oftare också att journalisterna själva bidrar till att skapa pseudohändelser som kan generera bra bilder och journalistiska berättelser. Genrer som intervjuer och debatter i tv är en del av denna tendens.

Vi kommer i denna artikel analysera ett exempel på hur presssen bevakar en pseudohändelse, fotograferingen av partiledarna i riksdagen. Samtidigt som tidningen tillskriver en särskild mening till både händelsen och sig själv genom iscensättningen av fotograferingen och den mening som fotografer skapar. Vi har valt denna bild för att den inrymmer ambivalenser i flera dimensioner:

- mellan om det är medierna eller källorna som skapar pseudohändelse, 
- mellan den planerade betydelsen och den betydelse bilden faktiskt kom att få och

- mellan bildjournalistikens dokumentära tradition och andra traditioner inom fotografi.

\section{Grader av planerat pressfoto}

En rad studier pekar på att fotojournalistens uppgift ofta är att bekräfta en existerande textbaserad nyhetshistoria och att stötta en journalistisk vinkel som redan är fastlagd (t ex Gynnild 1990, Olsson 2000, Ekström 2006, Jamtøy 2011). Utifrån denna forskning samt teorier om pseudohändelser och våra insikter från denna studie (observationer och intervjuer) har vi analytiskt delat in bildjournalistiken i ett kontinuum av bildtyper som går från journalistiskt bestämda till situationellt bestämda ${ }^{1}$.

1. Vid det beställda och iscensatta fotografiet har fotografen utifrån en klar vinkel fått en uppgift att ta ett bestämt motiv - som regel med mycket klara riktlinjer för utformning och uttryck. Soffbilden är ett exempel på detta. I denna genre finner vi också det som kan kallas det tillspetsade pressfotografiet som är tydligt uppställt och iscensatt ofta på ett kommenterande och humoristiskt sätt ${ }^{2}$. Denna typ av bilder visar pseudohändelser i Boorstins betydelse (1992), eftersom dessa händelser inte skulle existera om inte tidningen hade initierat dem.

2. Vid det beställda illustrationsfotografiet har fotografen fått till uppgift att ta ett fotografi som ska illustrera eller på ett annat sätt stötta något på ett förutbestämt sätt. Ofta något som redan är producerat (jmf Olsson 2000: 104). Beställningen av "en betryckt Mona Sahlin" är ett exempel på ett sådant fotografi.

3. Vid det redaktionellt planerade feature-och reportagefotografiet har fotografen fått i uppdrag att bevaka en särskild händelse eller ett ämne, men utan några riktlinjer som beställer en vinkel, motiv eller uttryck.

4. Vid det redaktionellt planerade nyhetsfotografiet skickas fotografen ut för att täcka en särskild händelse, men utan klara riktlinjer för vinkling, motiv eller uttryck. 
5. Vid det oplanerade pressfotografiet är bilden inte beställd eller planerad, varken av redaktion, reporter eller fotograf. Men en fotograf befinner sig i en situation som verkar nyhetsmässig och tar bilder. Det kan också (i växande grad) vara läsare som tar bilder med mobiltelefoner eller egna kameror och skickar in till redaktionen.

Ju längre ner vi kommer på listan, desto mindre griper tidning och fotograf aktivt in i regissering och uppställning av motiv och händelser, och desto mer traditionellt dokumentärt kommer fotografiet att vara. I alla fem typer av fotojournalistik kan det fotograferade dock vara planerad och iscensatt av andra som vid presskonferenser, arrangemang och liknande. När arrangörer primärt har skapat händelserna utifrån en önskan om (foto)journalistisk bevakning, kan man tala om pseudohändelser.

Olsson (2000:85) har argumenterat för att man inte bara ska skilja mellan olika grader av regissering som skapats av fotograf och redaktion, men också mellan situationer tagna med eller mot motivets vilja eller avsikt. Han pekar på att det politiska pressfotografiet i perioden 1925 till 1990-talet har ändrat sig från att domineras av bilder som politiker önskar bli publicerade till bilder som journalisterna men inte politikerna vill ha publicerade: "Journalisterna har [...] fătt större makt över representationen av politikerna och politiken" (Olsson 2000: 107). Som en del av denna maktförskjutning har också, hävdar vi, konstruktionen av en pseudohändelse i en valrörelse förskjutits från att i första hand varit politikernas aktivitet till att också vara journalisternas. För att illustrera detta samspel mellan politiker och journalister i den gemensamma etableringen av en pseudohändelse analyserar vi processen, produkten och utbredningen av den så kallade "soffabilden" som ett exempel på detta. Men låt oss först beskriva arbetsprocessen på Svenska Dagbladets bildredaktion.

\section{Bildredaktionen på Svenska Dagbladet}

Innan vi redogör för den konkreta arbetsprocessen som ledde fram till soffbilden, ska vi beskriva hur bildredaktionen på Svenska Dagbladet arbetade 2010. Där fanns det då nio fotogra- 
fer och sex bildredaktörer (varav en var bildchef). Bildredaktionen satt mitt i det öppna kontorslandskapet, invid redigeringen, webbredaktionen och nyhetsdesken. Något mörkrum finns inte sedan länge, allt bildarbete sker digitalt på skärm. Bildredaktörerna sitter vid desken tillsammans med nyhetschefer och webbredaktionen, och deras uppgift är både att både gå igenom de närmare 3000 bilder som kommer varje dag från bildbyråerna och att arbeta med de egna fotograferna. Ca 25-30 procent av alla bilder i tidningen tas av de egna fotograferna.

Under fyra dagar i början av september 2010 gjorde vi en redaktionsstudie vid bildredaktionen på SvD. Då framträdde följande mönster i bildproduktionen, en arbetsgång som återkom hela tiden:

1. Bildredaktören diskuterar tänkbara bilder med nyhetschefen, och är ibland med på de olika avdelningarnas möten för att se vad som är på gång. Bildredaktören håller i arbetslistan för fotograferna och letar bilder i flödet från nyhetsbyråerna.

2. Bildredaktören pratar löpande med de olika fotograferna om uppdragen, förklarar vilken slags bild det är och koordinerar med reportern (t ex om reportern ska följa med).

3. När fotografen kommer tillbaka från sitt uppdrag gör han/ hon en grov genomgång, och plockar ut 10-15 bilder från de kanske flera hundra exponeringarna. Bildredaktör och fotograf går igenom dem tillsammans på skärmen och diskuterar vilka som fotografen ska kopiera och göra klart för publicering. Till ett vanligt jobb lämnar fotografen kanske 3-5 bilder ${ }^{3}$.

4. Bildchefen diskuterar bildval med nyhetschef och redigerare som sätter ihop sidan. Men det är bildredaktören som har sista ordet när det gäller bildvalet, och som gör den sista kollen på bilden innan sidan går iväg.

Det är bildredaktörerna som har den centrala rollen i den dagliga bildproduktionen. Bildredaktören finns med i hela processen, även om bildidéerna ofta utgår från den journalistiska vinkeln - t ex att det ska vara en bekymrad Mona Sahlin på bilden till de dåliga opinionssiffrorna. Bilderna väljs utifrån ett ett upplägg som diskuteras fram med nyhetscheferna, uppdragen läggs ut på fotograferna eller bilderna tas från bildbyråer som Scanpix, som 
är den helt dominerande bildbyrån i Sverige. Samtidigt arbetar fotograferna självständigt, både med kortare jobb och med längre uppdrag där bilderna ska användas senare. Fotograferna vill också oftare komma ut på reportage för att inte känna sig så styrda av nyhetsvinkeln.

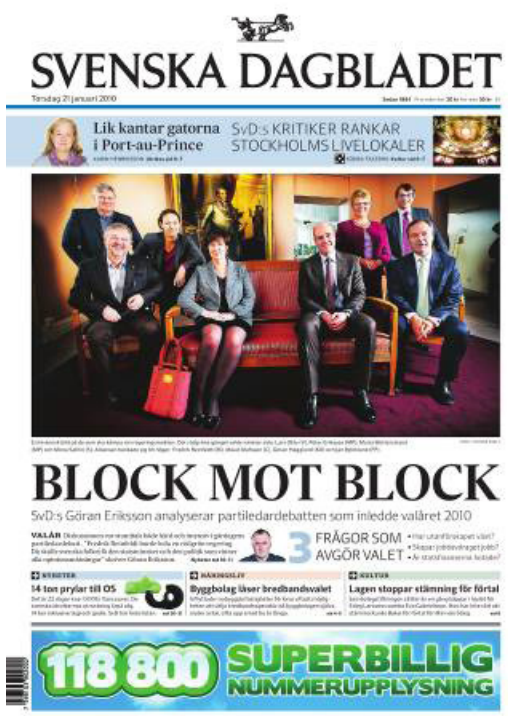

\section{Så skapades "soffabilden"}

Vår undersökning av ett konkret exempel på den planerade fotojournalistiken tar sin utgångspunkt i en den bild som Yvonne Åsell tog för Svenska Dagbladet i början av 2010. Den visar Sveriges åtta partiledare fram till valen i september 2010. Kring soffans högra sida (i vänstra sidan av bilden) är de röd-gröna placerade - i soffan sitter Mona Sahlin (s), bredvid henne på en stol sitter Peter Eriksson (mp), bakom henne står Maria Wetterstrand (mp) och Lars Ohly (v). Den borgerliga alliansen är placerad kring soffans vänstra sida (till höger i bilden) där Fredrik Reinfeldt sitter i soffan med Jan Björklund (fp) på en stol bredvid. Bakom dem står Maud Olofsson (c) och Göran Hägglund (kd)

Idén till soffbilden föddes på ett "covermöte" i december 2009. Varje vecka har några chefer och en bildredaktör ett möte för att diskutera omslagsjobbet som täcker 5-6 sidor i söndagstidningen, och nu gällde det den första "covern" för valåret 2010. Bildredaktören Jessica Olofsson berättar: 
Politikredaktionen hade lite idéer, men det var svårt att ro hem en så stor cover bildmässigt. Då fick jag idén att kan vi inte plåta alla partiledarna samtidigt tillsammans. Det verkade inte vara så många som tänkt på det och politikredaktionen såg lite förvånade ut.

Även den andra bildredaktören som stod för det dagliga arbetet tyckte det var en bra idé, och hon började kolla med partiernas pressekreterare innan hon lade ut jobbet på fotografen Yvonne Åsell. Hon började ringa runt och hittade en dag då de alla skulle vara samlade i riksdagen för en partiledardebatt. Moderaterna sa nej först, men ändrade sig - "det var ju valår så det var lättare att få alla att säga ja, alla ville vara till lags och vara med", berättar Yvonne Åsell. Alla kontakter gick genom partiernas pressekreterare, som sedan pratade med partiledarna.

När Yvonne Åsell fått ja från alla, fick bildredaktören veta att den cover som bilden skulle illustrera hade tidigarelagts och man skulle inte hinna ta bilden. Då blev både hon och Yvonne Åsell riktigt upprörda, och tillsammans med inrikeschefen bestämde man att bilden skulle tas och publiceras redan dagen efter med en ledsagande text från en politikreporter. Bildidén hade blivit så förankrad att bilden i sig motiverade en text - istället för att som från början vara en illustration till en textidé.

Men var skulle bilden tas? Riksdagshuset är stort, och Yvonne Åsell var där i flera dagar i förväg för att hitta ett lämpligt rum som inte låg alltför avlägset, men som ändå gav en miljö som visade att det var riksdagshuset. Hon hittade rummet med soffan, några fåtöljer och tavlor som gav en fin miljö. Tiden bestämdes till strax före lunch, och tillsammans med en annan fotograf som var med som assistent hade Yvonne förberett med möblering och ett litet extra ljus från sidan.

Då när jag skulle ta bilden visste jag inte om de skulle komma alla... Det skulle tas någon sån här bild tidigare, men då sa de att Sahlin var hungrig och det tog för lång tid. Jag sa faktiskt det till moderaterna, och tror att det var det som gjorde att de kom. Men det roligaste var att Maria Wetterstrand inte var med på debatten, men hon kom dit för bilden.

Själva fotograferingen var över på 5-10 minuter. Yvonne Åsell placerade ut partiledarna, de två stora partierna i soffan och de 
andra i blocken stående runt omkring. Det svåraste var att hålla fotograferna från andra tidningar, som följde partiledarna, ute från rummet och fotograferingen.

Jag sa verkligen till att jag jobbat med den här bilden i evigheter så ni kommer inte in. De ville ställa sig på andra sidan, men jag sa nej ni kommer inte in. Ni får fixa det själva, sa jag.

Av de flera hundra exponeringarna valde Yvonne Åsell två: en där de sitter i soffan, en mer uppsluppen och mindre formell till insidan. I kopieringen gjorde hon färgerna mer mättade och mörkade ner i kanterna runt om för att framhäva de åtta partiledarna. Bilden är mer bearbetad än en vanlig nyhetsbild, något som bildredaktören Jessica lämnade över till Yvonne - "det är fotografens frihet att kopiera... om de håller sig inom rimliga gränser får de kopiera, det är en viss personlig stil i det, ett slags konstnärligt uttryck".

Bildchefen Joakim Ståhl säger att gränserna för hur mycket en fotograf får bearbeta en bild beror på vilken slags bild det är, i nyhetsbilder får man göra ganska lite medan mer är tillåtet i t ex kulturdelen.

I dokumentära bilder får man göra väldigt lite, det man förr kallade normal kopiering med att lätta upp och mörka ner, beskära och sätta fokus.... Egentligen är detta inte en dokumentär bild, och eftersom vi har skapat den tycker jag att vi kan tillåta oss mer. Däremot gjorde Yvonne en ny mer obearbetad version som hon skickade in till Årets bild, annars hade hon blivit ratad direkt.

Som beskrivningen av processen visar och som bildchefen själv säger, så är soffabilden inte dokumentär. Den är däremot ett bra exempel på exempel på planerad bildjournalistik. Men som fotografen Yvonne Åsell påpekar är arrangerade gruppbilder inte någon ny företeelse inom bildjournalistiken - de är mycket vanliga i lokaltidningar, och det finns även traditionella gruppbilder som t ex när de stora tidningarna fotograferar den nya regeringen utanför slottet efter första mötet med kungen. Även fotografen Lennart Nilsson gjorde en serie gruppbilder under 1960-talet, bilder som var mycket tydligt uppställda med olika kultureliter (Forsell 2002). 
Bildredaktören Jessica Olofsson värjer sig också mot beskrivningen att det skulle ha blivit fler planerade bilder.

Jag tycker inte det är samma sak [med soffbilden, förf. anm.]. För att kunna ta den bilden var vi tvungna att boka dem, jag tror inte att de är i samma rum vid samma tillfälle. För mig handlar det inte om planerad journalistik utan om möjligheten att ta en bild.

Fotografen Yvonne Åsell ser fördelar rent bildmässigt med en mer planerad journalistik, men det behöver inte innebära fler planerade och arrangerade bilder.

Då skulle man kunna planera bildjobben så att man ser när det bästa bildtillfället är. Om jag har ett jobb planerat nästa vecka så börjar jag kolla idag med de människor det handlar om och om de gör saker som är bildmässiga. Det skulle höja bildjournalistiken.

Inte heller bildchefen Joakim Ståhl ser inte någon motsättning mellan mer planerad journalistik, och att ändå sträva efter dokumentära bilder som inte är arrangerade.

Med mer planering kan vi vara med innan något har hänt, istället för att bara springa iväg på en pressträff. Vi jobbar mycket med access, att få tillgång till att vara med. Det tar mer tid, men det blir ofta väldigt bra... får man den accessen är det nästan alltid värt det som nu när vi var med Volvoledningen $i$ Kina.

Ett exempel på den mer planerade bildjournalistiken är den fortsatta valbevakningen 2010 på Svenska Dagbladet. När soffbilden publicerades, planerades samtidig den kommande valbevakningen. Varje fotograf fick i uppdrag att följa en partiledare fram till valet. De fick själva bygga upp kontakter med pressekreterare och hålla koll på vad partiledarna gjorde, åka med på valturnéer och partimöten. Syftet var att hitta bra fototillfällen och bygga upp kontakter för att på så sätt få tillgång till partiledaren och den inre kretsen. Då skulle SvDs fotografer kunna ta bilder som andra inte hade möjlighet till.

De två fotografer som fick mest utrymme var Yvonne Åsell, som följde Fredrik Reinfeldt, och Magnus Hjalmarsson Neideman som följde Mona Sahlin. Deras bildserier publicerades i 5-6 sidiga reportage när partiledarna porträtterades, och dessutom kunde de samla en bildbank där de plockade fram bilder 
som bildredaktörerna behövde för den dagliga bevakningen. Till exempel "en betryckt Mona Sahlin" när tidningen berättar om de senaste opinionssiffrorna. Även de andra partiledarna fick "sina" fotografer, men omfattningen på bevakningen blev mindre.

Upplägget fungerade fram till den sista månaden före valet. Då blev valrörelsen så intensiv att jobben bestämdes av bildredaktören, samtidigt som fotograferna kunde utnyttja sina kontakter för att förbereda bevakningen av valvakorna. Bevakningen av Mona Sahlin ledde också fram till ett tredjepris för årets bildserie i "Årets bild 2010" för fotografen Magnus Hjalmarsson Neideman.

\section{Svenska Dagbladets verbala och multimodala iscensättning av soffbilden}

Vi definierar alltså soffbilden som ett beställt och iscensatt fotografi - och därför per definition som en bild av en pseudohändelse. Fotograferingen är inte spontan, den kommer till uteslutande för att tidningen har planerat och organiserat den. Till detta kommer att bildens relation till den underliggande verkligheten är oklar, bilden visar en politisk verklighet med två block samtidigt som det är tydligt att uppställningen är konstruerad av tidningen. Den är både dokumentär och inte, och på det sättet skiljer sig den också från traditionella förstasidesbilder. Soffabilden är uteslutande skapad för att bli publicerad i SvD, men tidningen är också intresserad av vilken spridning bilden får i andra medier (se nedan).

Redan när idén till soffbilden kläcktes, när den förbereddes, och genom själva fotograferingen och efterbehandlingen var fotografiets betydelse, mening och funktion under konstruktion. Det var centralt för idén att inga andra (tidningar) hade tänkt på att samla alla partiledarna i ett gruppfoto. Själva bildidén blev så förankrad i redaktionen att den färdiga bilden i sig motiverade och initierade en "nyhet", med text och bild på förstasidan

Bildchefen uppfattade inte bilden som dokumentarisk, utan som ett motiv som tidningen själva skapade, och Åsells omfattande efterbehandling av särskild bilden på förstasidan understryker denna uppfattning. I de anställdas självuppfattning är 
fotografiet och historien något som SvD har skapat och som de är stolta över. Trots att det upplevs som fakta att valrörelsen är en kamp mellan två block, sticker man inte under stol med att bilden och historien utgör tidningens tolkning av den dåvarande politiska situationen. Bilden - och processen som skapade den förstås och konstrueras som en viktig händelse: Det handlar om en bra journalistisk idé som har gett upphov till en representation som fångar in det essentiella i den kommande valrörelsen. Denna självuppfattning och konstruktion av bildens och fotosessionens betydelse fördes vidare i SvD:s verbala och multimodala iscensättning av bilden.

Bilden presenterades på SvD:s förstasida 21 januari 2010. Den finns precis under tidningens titel och två hänvisningar till andra artiklar i tidningen. Den dominerar förstasidan genom att täcka sidan i hela dess bredd och lägga beslag på mer än 30 procent av sidan. Storleken och den framträdande placeringen tillskriver bilden betydelse. Bildtexten är:

En historisk bild på de som ska kämpa om regeringsmakten. Det rödgröna gänget valde vänstra sida: Lars Ohly (V), Peter Eriksson (MP), Maria Wetterstrand (MP) och Mona Sahlin (S). Alliansen bänkade sig till höger: Fredrik Reinfeldt (M), Maud Olofsson (C), Göran Hägglund (KD) och Jan Björklund (FP).

Under bildtexten bidrar huvudrubriken med förankring (jmf Barthes 1980) av bildens betydelse: "Block mot block". Orden styr uppmärksamheten mot det faktum att politikerna formerat sig som två visuella enheter i var sin sida av soffan, tydliggjort genom det lilla mellanrummet mellan Mona Sahlin och Fredrik Reinfeldt. De rödgröna i bildens vänstra sida och Alliansen till höger. I vänstra sidan stängs bilden av väggen höger om Eriksson och Ohly. I bildens högra sida ses en öppning ut ur rummet mot en korridor med en vit vägg. Helt till höger ser vi den mörka konturen av en person som står utanför. Bakom Reinfeldts huvud finns en till utgång som är ljusare än de ljusbruna väggarna som omger gruppen. Bakom Sahlin ses en tavla föreställande landtmarskalken Klas Fleming. På golvet till höger om Sahlin står en väska i en nästan strålande röd färg, med ett gyllene metallmärke. Väskan är en tillsynes betydelselös detalj, men den påminner om 
de attribut som på tavlor från medeltiden användes som symbol för bibliska personer och händelser eller renässansens ikonografiska koder för klassiska mytologiska personer. Som vi senare ska se blev denna symbol, väskan, oväntad den mest omtalade delen av Åsells bild.

Bilden skiljer sig från tidningars traditionella fotografier på förstasidan som vanligtvis är reportagebilder och endast i mycket sällsynta fall arrangerade (jmf. Becker 2000a). Medan reportagebilder är dokumenterande nyhetsbilder, är SvD:s arrangerade bild snarare att betrakta som ett illustrationsfotografi. Även om den illustrerar en aktuell politisk situation (Riksdagens partier uppdelade i två block), är bilden inte primärt dokumentarisk utan en visuell tolkning av denna situation. På så sätt framstår bilden som ett brott mot det dokumentariska kontraktet mellan pressen och läsaren. Detta kontrakt säger att journalister måste begränsa sig till att rapportera nyheter och inte får bidra till att initiera eller själva skapa dem. Fotosessionen i Riksdagen är på så sätt en pseudohändelse eftersom den enbart har skapats för att bli rapporterad och inte skulle ge någon mening om inte fotografen varit närvarande.

Bilden är ett fotografiskt grupporträtt, en genre som har sina rötter i 1800-talets porträttkultur. I historiskt perspektiv har porträttfotografiet styrts av två olika tolkningssystem: ett förtryckande och ett socialt bekräftande och legitimerande. Porträtt har inviterat beskådaren till två olika offentliga typer av betraktande: antingen att se ner på de mindervärdiga eller att se upp till de som var bättre än man själv var (Lien 2008). Soffbilden tycks ha spänts ut mellan dessa två positioner. Bilden drar på välkända traditioner inom det uppställda gruppfotografiet, som klassbilden, det uppställda familjefotografiet eller officiella gruppbilder av deltagare i ett toppmöte, t.ex. inom FN eller EU. Alla dessa bildtraditioner syftar till att dokumentera speciella situationer. Uppställda familjefotografier görs vid viktiga sammankomster, fester eller situationer där något särskild har gjort att familjen samlas. Gruppbilderna av ledare tas vid avgörande händelser som toppmöten eller underskrivandet av traktat.

I alla dessa fall utstrålar framställningen något högtidligt, formellt och officiellt. Ledarna framträder i sina roller som politiker - mer än som privatpersoner - och familjemedlemmarna 
och skolbarnen framträder i högre grad som medlemmar i en grupp än som oberoende individer. Förstasidesbilden placerar sig således inom bildgenrer som präglas av homogenisering av den enstaka individen, tradition och en viss högtidlighet, vilket understryks av bildens statiska - och något stela - karaktär och personernas placering under riksmarsken, samlade kring den eleganta soffan. Ingen är i rörelse, alla står eller sitter still. De flesta har händerna ihop framför kroppen. Alla tittar in i kameran, mot åskådaren, och det finns ingen interaktion mellan dem.

Att använda denna bildgenre på förstasidan går på så sätt stick i stäv med två tendenser inom samtidens journalistik och pressfotografi. Den första är tendensen att presentera politiker som vanliga människor snarare än politiker, som personer snarare än offentliga roller. Den andra är tendensen mot oberoende, objektiv rapportering. I vår undersökning av förstasidorna på fyra tidningar (Expressen, Aftonbladet, Dagens Nyheter och Svenska Dagbladet) från 17 augusti 2010 till valdagen 19 september fanns det inga exempel på iscensatta bilder med politiker. Bilden och dess dominerande placering på förstasidan iscensätter på så vis inte bara de avbildade personerna som politiker och parlamentariska block, utan främst tidningen som ceremonimästare. Svenska Dagbladet görs till en institution som genom sin visuella summering av block-mot-block situationen så att säga ger startskottet för valrörelsen. Skillnaderna mellan de enstaka partierna suddas ut till fördel för en presentation av de två lagen samlade på var sin sida och med ett passande avstånd sinsemellan, redo för kamp. Politikerna agerar inte. De är just "uppställda” för tidningens - och läsarnas - skull.

Inuti tidningen visas Åsells andra bild från soffan i ett uppslag på sidorna 10-11. Här är kompositionen och personernas kroppsspråk mer dynamisk och informell. Medan Alliansen framträder på i stort sett samma sätt som på förstasidan, har tre av de rödgröna (Sahlin, Wetterstrand och Ohly) blicken vänd mot Alliansen och de framträder därför i profil. Eriksson tittar svagt uppåt och snett mot vänster med ett närmast frånvarande - eller drömmande eller visionärt - uttryck. Här framstår politikerna som mindre formella, mer avslappnade och levande. Den lösare kompositionen och nerbrytningen av de tydliga visuella block som vi såg på förstasidan, gör situationen mer spontan och autentisk 
- och därmed mindre konstruerad - och framställningen låter i högre grad politikerna framträda som individer. Den verbala förankringen i huvudrubriken stödjer dock förstasidans tolkning av valrörelsen som en kamp mellan två block: "Tydliga stridsfrågor startar valår". Samma sak gäller bildtexten, vars första del säger:

Detta är en historisk bild på dem som ska kämpa om regeringsmakten i åtta månader. Sällan kan man få alla partiledare och språkrör samlade vid ett fototillfälle. Bilden är också tidstypisk, se bara vilket behörigt avstånd som de båda statsministerkandidaterna vill ha mellan sig i soffan. Allt medan landtmarskalken Klas Fleming vakar över arrangemanget.

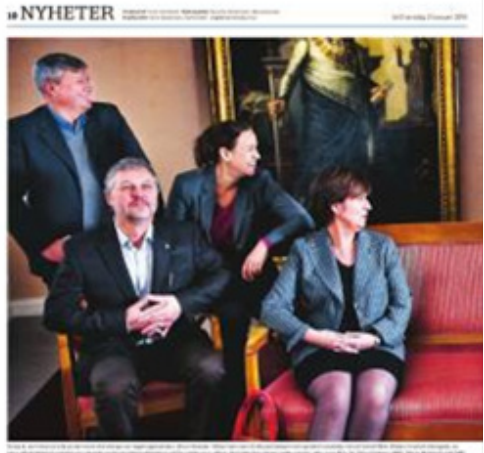

Tydliga stridsfrågor

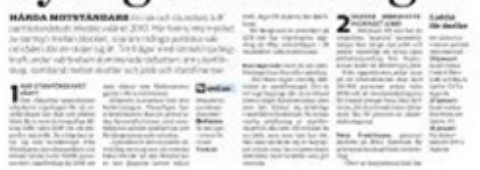

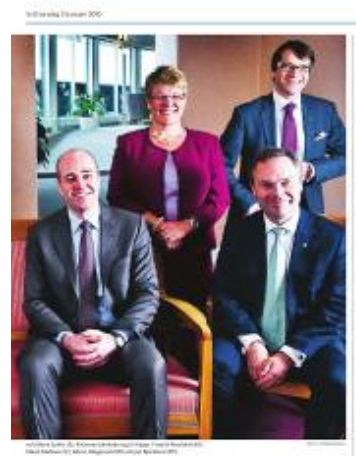
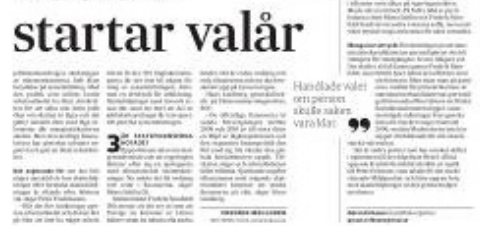

Här fortsätter SvD:s iscensättande av bilden som et speciellt, närmast ikoniskt fotografi. Som på förstasidan kallas det "historiskt”. Det verkar främst bero på att det sällan går att samla alla partiledare och språkrör vid ett fototillfälle. Det nämns att bilden är "tidstypisk" därför att den visar upp ett tydligt avstånd mellan blocken. Samma tolkning och iscensättande gav redaktionschefen Martin Jönsson uttryck för i sin blogg (21 eller 20 januari), när han under rubriken "Klassisk bild från valrörelsen 2010" skrev att "vissa bilder känns klassiska redan när man ser dem. Yvonne Åsells förstasidesbild på alla partiledarna i dagens SvD är en sådan”. Han berättar hur SvD har jobbat för att få till stånd 
bilden, hur Åsell fick "mota bort nyfikna fotografer, journalister och tv-team som hängde i korridoren", och han tackar bildredaktionen för "ett oerhört bra jobb". Han slår fast att det var givet hur partiledarna skulle sitta och att "avståndet mellan Sahlin och Reinfeldt var symboliskt stort". Men, skriver han, "bilden blev tagen - och blev fantastisk. Nu har valrörelsen börjat."

I SvD:s textuella iscensättande läggs det alltså mindre vikt vid politikerna och valrörelsen och mer vid hur tidningen - trots en mängd utmaningar - lyckades att skapa situationen och ta bilden. Bilden framställs som "historisk", "tidstypisk", "klassisk" - och "fantastisk". Men med tanke på att bilden är ett fotografi av en pseudohändelse - en SvD-planerad fotosession - är det nog snarare så att Sverige befinner sig i en historisk politisk situation, som fotografen skapat en iscensatt illustration av. Det är med andra ord skillnad på en historisk situation och en historisk bild.

Hittills har vi pratat om "soffbilden" i singular, som om det handlade om en enstaka bild. Men på uppslaget inne i tidningen ser vi att det faktisk inte är tal om bara en bild. "Soffbilden" är, som vi ovan antydat, inte en enstaka, avgränsad bild, utan snarare en visuell föreställning. I överensstämmelse med W.J.T. Mitchells argument om att gränserna mellan materiella och mentala bilder ofta är flytande (Mitchell 1986), illustrerar iscensättningen - och fotografiets senare spridning - att soffbilden snarare kan betraktas som en generell fotografisk diskurs. Det blir tydligt när man tar med iscensättningen av bilden på SvD:s hemsida. 21 januari presenterar svd.se en bildserie under rubriken "Här tas en historisk bild".

Den ger en kronologisk redovisning av fotosessionen. Fotoserien börjar - symboliskt - med en bild av den tomma soffan, sedan några bilder på de rödgröna, som uppenbarligen ankommer först och placerar sig i soffans vänstra sida. Alliansen ankommer och hälsas välkommen, partiledarna placerar sig kring soffan, och sen kommer bilden från uppslaget sidorna 10-11. Därnäst förstasidesbilden och slutligen en bild av partiledarna som resar på sig från soffan och lämnar rummet. Därefter kommer en rad bilder av Sverigedemokraternas partiledare Jimmy Åkesson. Denna webbpresentation av soffbildens tillblivande bidrar till att iscensätta fotografiet som något speciellt. Implika- 

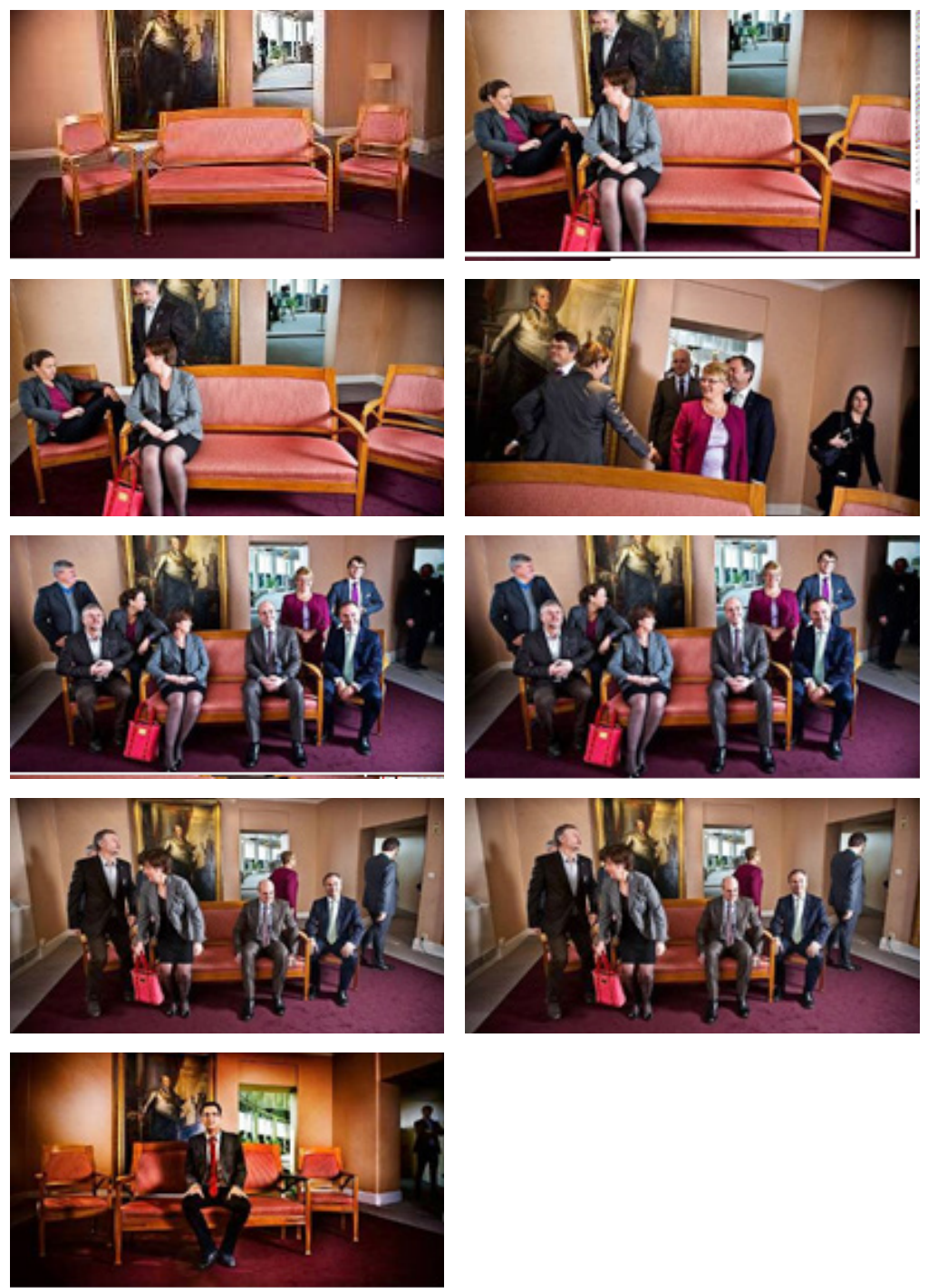

tionen är att SvD skapat något unikt och att det därför är relevant att läsarna får en möjlighet att uppleva hur denna "historiska" bilden har kommit till. Medan förstasidesbilden som sagt ger en traditionell, uppställd och formell representation av partiledarna, som visar dem front-stage (jmf. Meyrowitz 1985) i rollen som politiker, ger webbserien en blick back-stage som presenterar partiledarna informellt, off guard (jJmf. Olsson 2000: 104) och mer personligt i rollen som sig själva, som individer. 
Genom att skriva soffbildens historia och berätta om dess tillkomst, bidrar SvD till att fastställa fotografiets betydelse. Denna berättelse om bilden fortsätter när det åter publiceras på valdagen 19 september. Bilden sprider sig över två helsidor (s. 8-9), huvudrubriken låter: "Snart i mål", och ingressen berättar:

SvD-fotografen Yvonne Åsells gruppbild på riksdagens partiledare är sannolikt årets mest publicerade bild - och fortfarande den mest talande illustration av valrörelsen 2010
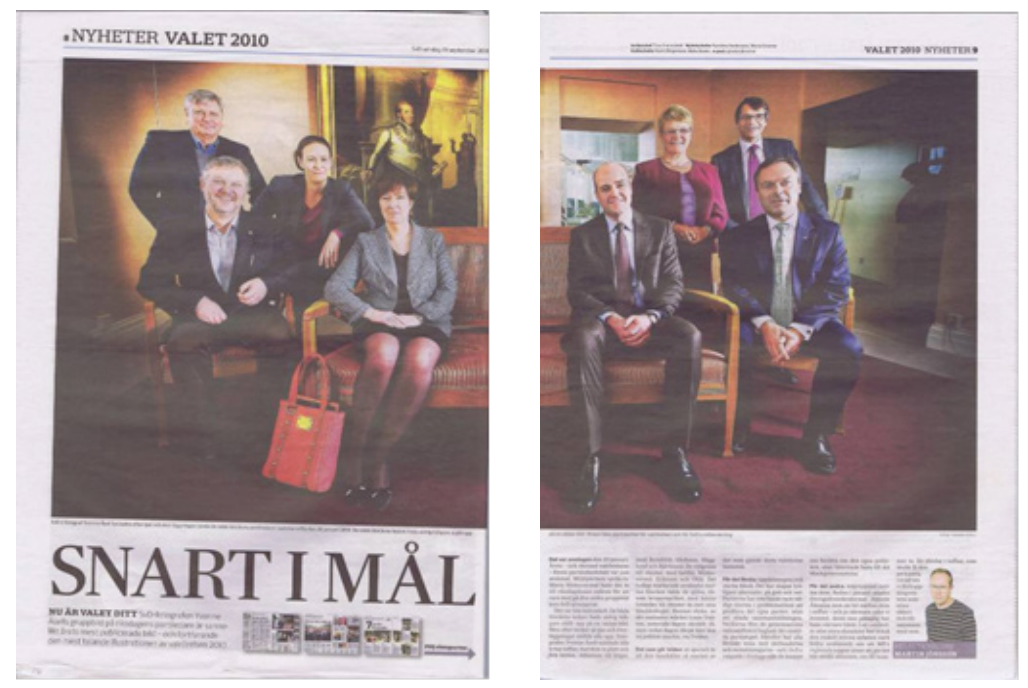

I brödtexten berättar redaktionschefen Martin Jönsson - som i tidigare texter - hur bilden tillkom och hur svårt det var att ta fotografiet. Och som tidigare förklarar han, vad "som gör bilden så speciell", nämligen "uppdelningen i två starka block" och "tomrummet mellan dem". Han nämner att Sahlin lutar "åt vänster mot sina blockkollegor" och skriver att "[h]ennes väska, av det exklusiva märket Louis Vuitton, noterade ingen särskilt då, men redan dagen därpå blev den en politisk snackis via Twitter”.

\section{Bildens spridning}

Enligt Martin Jönsson är soffbilden alltså sannolikt "årets mest publicerade bild". Men så är förmodligen inte fallet. Bilder från 
SvD:s fotografer säljs via bildbyrån Scanpix, och varken tidningen eller de enskilda fotograferna får någon redovisning av vilka som köpt in deras bilder. Det går därför inte att göra någon detaljerad analys av vilken spridning "soffbilden" fick. Men enligt Scanpix egna siffror laddades bilden ner 170 gånger under 2010, vilket ger den en 29e plats på listan över de mest nerladdade enstaka bilderna. De allra flesta nerladdningarna gjordes i januari i samband med publiceringen och väskdebatten, och 131 av nerladdningarna gjordes av nyhetsmedier (resten av tidskrifter, förlag $\mathrm{mm}$ ). "Mycket för att vara en enskild bild, men inte på något sätt exceptionellt" enligt Scanpix redaktionschef Max Schagerström (information per mejl 2011.03.21). Ett avgörande hinder för att bilden skulle kunna få en omfattande spridning är förmodligen att bilden så tydligt är SvD:s idé och verk. Det är denna tidning som planerat och arrangerat fotograferingen och genom den ursprungliga publiceringen på förstasidan slutgiltigt har visat sitt "ägande" av bilden. I en bransch där det att vara ensam om en nyhet och äga den är avgörande för ens succé, resulterar detta $i$ att bilden potentiellt blir mindre intressant för andra tidningar.

Även om bilden förmodligen inte är årets mest publicerade bild, fick den ändå stor spridning. Om man ska döma efter SvD:s egen beskrivning och iscensättning av bilden i tidningen, beror spridningen på bildens fotografiska kvaliteter, men antagligen var Mona Sahlins väska en lika viktig orsak. De flesta svenska nyhetsmedierna laddade ner och publicerade soffbilden i samband med den första publiceringen i januari och i samband med den debatt om Mona Sahlins väska som följde.

Den röda och tillsynes obetydliga väskan som står vid Sahlins vänstra fot, visade sig vara ett fotografiskt element, en detalj, som i viss mening störde och punkterade den avsedda och mer grundläggande meningen med bilden (de två blocken). Den ådrog sig uppmärksamheten och skapade en ny betydelse. ${ }^{4}$ Den redaktionella och institutionella betydelsen i bilden som SvD beredde vägen för i sin iscensättning ("Block mot block"), åsidosattes i debatten om Mona Sahlins Louis Vuitton-väska till drygt 6000 kronor. Den formella representationen av personerna i rollen som politiker och partiledare, blandades med moraliska överväganden kring personliga assesoarer. I dagarna efter publiceringen uppstod en upphetsad debatt om huruvida dyra mär- 
kesprylar gick stick i stäv med det en socialdemokratisk ledare ska representera. Väskdebatten fick plats i många nätforum samt i bl.a. Aftonbladet, Expressen, Dagens Nyheter samt på svt.se. Aftonbladets politiska kommentator Lena Melin ansåg att partiledarens val av väska inte var särskild genomtänkt, eftersom det inte överensstämde med Sahlins huvudfråga under valrörelsen, nämligen de ökade klyftorna i samhället. ${ }^{5}$ Tidningens ledarskribent Katrine Kielos ansåg däremot att Mona Sahlin hade rätt att själva bestämma vad hon ville lägga sina pengar på. ${ }^{6}$ I Expressen var rubriken "Här poserar Mona Sahlin med 6000 kronors handväska”.7 På debattsajten Newsmill kallade Göran Greider från Dala-Demokraten Sahlins väska för ett hot mot socialdemokratin. ${ }^{8}$ Debatten gick på en mängd tidningar, webbplatser och bloggar ${ }^{9}$ vilket bidrog till spridningen av bilden.

\section{Soffbildens retoriska och estetiska kvaliteter som ikoniskt fotografi}

En orsak till bildens spridning är alltså utan tvekan väskdebatten, men enligt SvD:s egna ord och iscensättningen såväl i den tryckta tidningen som på webben måste spridningen också bero på bildens retoriska och estetiska kvaliteter som ikoniskt fotografi. Tidningens beskrivning av fotografiet som unikt, som den mest publicerade bilden och som "den mest talande illustrationen av valrörelsen 2010" påminner mycket om de karaktäristikerna vi har av så kallade "ikoniska bilder”. Och även om bilden skiljer sig från många ikoniska bilder inom nyhetsfotografi bland annat därför att det är arrangerad - har det vissa ikoniska drag. Hariman och Lucaites beskriver i No Caption Needed ikoniska fotografier som:

those photographic images appearing in print, electronic or digital media that are widely recognized and remembered, are understood to be representations of historically significant events, activate strong emotional identification or response, and are reproduced across a range of media, genres, or topics. (Hariman \& Lucaites 2007: 121, kursiv i original). 
Det finna inte många bilder som uppfyller alla dessa kriterier. Hariman och Lucaites hävdar att det egentligen bara tillkommer 20-30 verkligt ikoniska bilder under loppet av ett par generationer. Det handlar om fotografier som Joe Rosenthals bild av amerikanska soldater som reser flaggan på Iwo Jima (1945) eller av den ensamma kinesen framför fyra stridsvagnar under studentupproret på Himmelska fridens torg (1989, jmf. Hariman \& Lucaites 2006). Men trots allt passar fler av ovan nämnda kriterierna på soffbilden. Den är allmänt känd, har en spridd publicering och uppfattas som en dominerande representation av den svenska valrörelsen 2010. Den har reproducerats i en rad medier, även om det inte har skett i andra uttrycksformer som t.ex. t-shirts, muggar, konstverk eller dylikt.

\section{En ikonbild för valrörelsen? De retoriska och estetiska kvaliteterna i soffbilden}

Även om SvD alltså beskrev och iscensatte bilden som en form för ikoniskt eller unikt fotografi, är fotografen och journalisterna mer återhållsamma i sina formuleringar i våra forskningsintervjuer. Fotografen Yvonne Åsell säger att hon inte "vet om det är en så himla bra bild. Det är bra att man har fått ihop dem, det är väl det man får vara nöjd med”. Andra kvaliteter i bilden som hon nämner är att det syns att det är i Riksdagen, att det ser lite pampigt och högtidigt ut. Hon hade inte heller några andra bilder i tankarna när hon planerade bilden:

Det enda var i så fall en mer klassisk Lennart Nilssonbild, men han fick ihop sina gruppbilder i en studio. Vi har varken studio eller plats och den tiden finns inte.

Även bildredaktören Jessica Olofsson nämner i första hand det faktum att man lyckades få ihop alla på samma bild som den främsta kvaliteten, samt att de grupperade sig med det lilla mellanrummet mellan Sahlin och Reinfeldt. Hon gör också kopplingen till ett gammalt skolfoto: 
Det är extremt uppställt, nästan som att de sitter på ett skolfoto. Det är kanske inte så man är van att se partiledarna, man är van att se dem i talarstolen eller ute bland folk. Här är de uppställda alla tillsammans, alla tittar in i kameran. Jag tror att det är det som gör att bilden kändes unik.

Även bildchefen Joakim Ståhl säger att det var en prestation att få alla att ställa upp. Men relationerna inom de båda politiska blocken är också något som syns i bilden, vem som står var. Joakim Ståhl säger dessutom att bilden blev en slags ikon för hela valet 2010, särskilt som den röda Vuittonväska som Mona Sahlin hade med sig startade en debatt om en s-ledare kan ha en så dyr väska - "det visste vi inte när vi publicerade bilden, men det upptäckte kollegorna på Aftonbladet".

Joakim Ståhl säger att det inte är så ofta man publicerar den typen av arrangerade gruppbilder

Det är ju en fiktiv bild på det sättet att det är ju vi som har skapat den, situationen uppstod inte av sig själv. Den typen av arrangerade nyhetsbilder gör vi extremt sällan i nyhetsjobb, och därför kanske kraften blir lite större hos oss [...]. Vi har en ambition att det ska vara en verklighet som vi skildrar. Men inför en valrörelse så fanns det inte så mycket verklighet att skildra och vi ville hitta starten för att sätta igång vår valbevakning. Men i första hand vill vi ha dokumentära bilder, det är det vi ser som vår uppgift att ha.

Både fotografen Yvonne Åsell och bildredaktören Jessica Olofsson tvekar inför att kalla soffbilden för en ikon för valet 2010 . Yvonne Åsell anser inte att det fanns någon enskild bild som blev en "ikonbild", och när priset för Årets bild delades ut i mars 2011 var det bara en belönad bildserie som handlade om valet (av en annan SvD-fotograf). Jessica Olofsson betonar att det är en bra bild av Yvonne som visar hur det såg ut i politiken inför valet:

Ikonisk, då täcker jag att det finns många dubbelmeningar, att den symboliserar något annat men det tycker jag inte att den gör för det är en otroligt rak och bra nyhetsbild hur det ser ut när valrörelsen drar igång. 
En bra bild, säger Olofsson, men vad är egentligen en bra bild och vad behövs för att något kan definieras som en ikonisk bild? Hariman och Lucaites (2007: 28 ff.) arbetar utifrån fem antaganden om de retoriska appellerna i ikoniska bilder. För det första appellerar bilderna genom att representera händelser i överensstämmelse med traditionella konventioner inom visuella konstarter och persuasiva praktiker - deras uttryckssätt är estetisk välkända (aesthetic familiarity). För det andra tillåter bilderna en form av retoriskt medborgarskap (civic performance) genom att de (re)presenterar sociala händelser och beteenden och ger oss åskådare en möjlighet att själva värdera detta och betrakta oss själva i ljuset av det som framställs. För det tredje är ikoniska bilder öppna för olika tolkningar vilket ger möjlighet för semiotiska omskrivningar (semiotic transcriptions). För det fjärde erbjuder dessa bilder en stark gestaltning av emotionella erfarenheter (emotional scenarios). Och slutligen, för det femte, kan ikoniska bilder fungera som en estetisk resurs för att framställa och behandla tvister och kriser (contradictions and crises).

En studie i prisbelönade pressfotografier lyfter fram vissa drag som kännetecknande för dessa bilders retoriska kvaliteter. Vanligtvis handlar det om bilder i vidvinkel (long-shot/wide-shot) som avbildar en generell scen med människor i helfigur eller närbilder av en eller två personer. Människor är alltid det mest viktiga och de placeras därför oftast i bildens centrum, vanligtvis med expressiva och emotionella ansikts- och kroppsuttryck. Generellt är kompositionerna rena och enkla med endast få element eller personer, och ofta har de organiserats som kontrast eller motsats, vilket semiotiskt sett skapar betydelse genom en synekdokisk relation där en del representerar en helhet (Kjeldsen 2011).

Ett flertal av de estetiska och retoriska kvaliteterna som framhävs i ovan nämnda studierna kan vi även se i soffbilden. Det blir tydligt om vi undersöker bilden utifrån det som har kallats bilders retoriska kvaliteter (t.ex. Kjeldsen 2002, 2009; se även Kjeldsen 2006: 281 ff). Den första kvaliteten är bilders förmåga att skapa närvaro. De placerar människor och händelser framför oss som om vi stod framför dem i verkligheten. När vi ser partiledarna samlade kring soffan, upplever vi det som om vi stod 
framför dem i samma rum. Detta hänger ihop med den andra retoriska kvaliteten i bilder, särskild fotografier, som är den realism och dokumentation de erbjuder. Vi tvivlar - i utgångsläget inte om att partiledarna rent faktiskt har varit samlade i rummet och att de verkligen satt så som vi ser det. Den tredje kvaliteten är den omedelbarhet som vi uppfattar bilden med, genom ett kort ögonblick har vi sett och förstått vad vi sett. Det är bland annat möjligt på grund av bilders förmåga att representera genom visuell förtätning. Det vill säga att en rad emotioner och resonemang potentiellt samlas och kondenseras i bilden. I den meningen att bilden vill kunna framkalla känslor och argument hos åskådaren.

Bilden är i vidvinkel (long-shot/wide-shot) och ramar in en scen med åtta personer. Den har en enkel, fast inte helt ren komposition som huvudsakligen består av två visuella grupperingar. Som tidigare nämnts är det mest uppenbara och retoriska draget just denna visuella kontrast, som skapas genom uppställningen i två block. Denna konstruktion har et omedelbart igenkännbart antitetisk mönster, som skapar mening genom en synekdokisk del-för-helhet representation Här representerar de enstaka partiledarna sina partier, och grupperingen av ledarna i två läger representerar sammanslutningen av å ena sidan de rödgröna partierna, å andra sidan Alliansens partier. Detta bjuder in till en synekdokisk tolkning av det svenska politiska landskapet som antingen vänster eller höger. Visuellt utesluts andra möjligheter och väljaren begränsas till ett val mellan två ömsesidigt exkluderande alternativ.

I så mening representerar bilden alltså en oöverensstämmelse. Men den äger inte samma starka expressiva emotionella uttryck som de flesta ikoniska prisbelönade bilderna. För det första är bilden statisk. Den formella uppställningen gör att bilden varken har rörelse eller dynamik, utan framstår som stel och fastlåst. Människornas kroppsspråk bidrar inte heller med någon rörelse, handling eller dynamik. Alla sitter eller står still. Ingen interagerar - varken med blick eller kropp. Alla tittar direkt mot kameran och ler. Eriksson, Olofsson och Hägglund ler med öppen mun, de andra med stängd mun. Mona Sahlin ler med ögonen, men munnens leende har tryckts ihop till en smal spricka som till och med pekar lite neråt. Över huvud taget verkar Sahlins kroppsspråk mer stelt och obekvämt än de andras. Eriksson, Reinfeldt 
och Björklund särar på benen, medan Sahlins ben är helt ihop. Skillnaderna i kroppsspråk är dock förmodligen för små för att resultera i någon avgörande skillnad i tolkningen av de två grupperna.

Utöver den visuella invitationen att uppfatta bilden som en representation av två block, bjuder bilden inte in till någon rationell förtätning av mening. Det är inte utan vidare möjligt att utläsa några argument eller resonemang ur bilden. Med sin statiska karaktär rymmer den inte heller någon emotionell förtätning som kan utlösas i åskådaren.

Även om politikerna uppenbarligen delas i två grupper (vänster och höger), är det dock visuellt tydligt att de tillhör samma överordnade grupp (partiledare/politiker). Det beror inte enbart på att de sitter och står på samma sätt, utan främst på det enkla faktumet att de finns inom samma bild och på så sätt har grupperats ihop. Detta understryks av användningen av vidvinkel, vilket tar oss närmare politikerna som helhet, något som dessutom får stöd av Åsells bearbetning som har gjort bilden mörk i kanten och därmed skapat en gemensam inramning av alla åtta politiker som en enhet.

Som beskrivits ovan bidrar uppställningen och tavlan av landtmarskalken till en officiell front-stage karaktär. Det understöds av att alla männen bär kostym och alla kvinnorna kavaj. Det är dock endast Alliansens manliga partiledare som använder slips. Bilden är dessutom i röda kungliga färger på golv och soffa, med gyllene nyanser på väggen och i tavlan. På så sätt inviterar framställningen till en tolkning av de åtta partiledarna som landets elit, samlade i maktens centrum i Riksdagshuset. Även om dessa personer har delats upp i två grupper, är de dock ändå närmare varandra än de är den vanliga svenska medborgaren.

\section{Slutsatser och diskussion}

Etnologiska metoder och innehållsanalys är vanliga metoder i medieforskning, men det är sällsynt att metoderna kombineras i en och samma studie. Ofta ställs olika metoder och perspektiv i konflikt med varandra, och olika traditioner i medieforskning definierar sig genom skillnaderna i relation till de andra. 
Gay Tuchman betonar att det inte behöver vara så, tvärtom kan en kombination av olika perspektiv hjälpa oss att förstå förändringar i nyhetsproduktionen (2002:82). Denna studie är en kombination av två av de perspektiv som Michael Schudson definierar när det gäller nyhetssociologi - nyhetsarbetets sociala organisation i kombination med kulturella perspektiv som sätter in nyhetsinnehållet i ett symboliskt system (2005). Genom att kombinera bildanalys och en närstudie av produktionsprocessen bakom bilden kan vi få en djupare förståelse av både själva bilderna och av de faktorer som påverkar det slutliga publicerade resultatet. Vi kan ställa grundfrågor som varför och hur gick det till? Genom att studera också processen bakom bilden, så blir de ambivalenser och motsägelser som bilden bär på tydligare än vid en traditionell innehållsanalys.

Soffabilden är ett tydligt exempel på en bild som kan studeras ur flera perspektiv. Den skapades i en komplicerad process där många intressenter var inblandade, såväl inom redaktionen som utanför. Det var inte bara fotograferna utan också bildredaktörer, en specialredaktion och arbetsledningen som deltog i processen och dessutom hade källaktörer (partiernas pressansvariga) också en central roll. Själva bilden är också mångtydig, den växer fram i skärningspunkten mellan bildjournalistikens dokumentära tradition och andra bildtraditioner med mer av arrangerade bilder.

Denna studie beskriver ett enda fotografi under den svenska valrörelsen 2010. Under hela valrörelsen publiceras tusentals bilder, bara den sista månaden fanns det i de fyra stora betalda dagstidningarna i Stockholm 891 fotografier av partiledarna på nyhetsplats. Flest bilder fanns i de två kvällstidningarna Aftonbladet och Expressen, medan Svenska Dagbladet publicerade 145 fotografier på partiledarna den sista månaden (Heppling 2011). Men genom att analysera soffbilden, både processen hur den kom till och själva fotografiet, kan vi diskutera pressfotografiets betydelse i den moderna journalistiken, hur den växer fram i ett samspel mellan medier och deras källor och hur bildens mening förskjuts i den efterföljande debatten i andra medier.

Man kan inte förstå soffbildens mening, betydelse och funktion som journalistik och retorik om man endast betraktar den som ett enstaka fotografi. Bilden bör förstås som en central del av en mer omfattande kontext och diskurs. Konstitutionen av 
soffbildens mening, betydelse och funktion börjar i redaktionen hos Svenska Dagbladet, där idén kläcks. Här har pressfotografiet en stark ställning. Bildredaktörerna finns med i alla led av planeringen, och denna bildidé föddes just vid ett sådant planeringsmöte. När politikredaktionen ändrade sina planer kunde bildredaktörerna hålla fast vid sin bildidé, och de skrivande reportrarna producerade text utifrån den planerade bilden.

Soffbilden var ett grupparbete, ett gemensamt arbete från två bildredaktörer och två fotografer (varav en fungerade som assistent vid fotograferingen). Jobbet tog flera veckor att planera, och redaktionen försäkrade sig om att bilden skulle vara exklusiv för SvD. Andra fotografer stängdes ute. Fotografen hade en frihet inom ramarna för bildidén till att välja plats för fotograferingen, att arrangera uppställningen och att efterbearbeta bilden mer än brukligt för en nyhetsbild. "En konstnärlig frihet”, kallar bildredaktören det. Genom hela planerings- och utförandefasen blir gränsen mellan vad som är en dokumentär nyhetsbild och arrangerade och bearbetade bilder otydlig. Soffbilden simulerar ett nyhetsfotografi, men planeringen, utformningen och presentationen är en form av planerad bildjournalistik som anknyter mer till feature och magasin, än till dagspressens dokumentära tradition.

Detta utsuddande av gränserna mellan det dokumentära och det konstnärliga, det planerade och det spontana, det objektiva och det subjektiva, den verkliga nyhetshändelsen och pseudo-händelsen, fortsätter i SvD:s iscensättande av bilden. Det finns en spänning mellan den arrangerade förstasidesbilden (de "egentliga" soffbilden) och den mer spontana och autentiska bilden på uppslaget sidorna 10-11. Båda bidrar till ge mening till varandra.

På samma sätt fungerar webbtidningens publicering av hela bildserien runt soffbilden som en sådan typ av extra bonus, som har blivit typisk för webjournalistiken. Man läser om något i tidningen - eller ser något på tv - och uppmanas att gå ut på webben för att "se hela filmen", "lyssna på klipp från intervjun" eller, som i detta fall, se historien bakom. Samtidig bidrar detta "bonusmaterial" till att iscensätta detta fotografi som något speciellt och ger hela situationen en dokumentarisk prägel. I sig är soffbilden, som vi beskrivet ovan, inte dokumentarisk i traditionell mening, 
utan planerad och arrangerad. Men beskrivningen på websidan förser bilden med en dokumentarisk aura genom att dokumentera hur bilden tillkom. Därmed tillskrivs såväl bilden som de journalistiska handlingarna vikt. Men även om rapporteringen och dokumenteringen av soffbildens tillkomst uppvisar en form av dokumentarisk karaktär, bygger även den på en pseudohändelse.

I skapandet och presentationen av bilden finns det, påstår vi, en typ av ambivalens i förhållande till vad som är och bör vara fotojournalistikens särart och uppgift i samhället. Denna ambivalenta tendens kom även fram i våra intervjuer med fotografer och redaktörer. Trots att det i allmänhet finns en ökad tendens mot planerad och förberedd journalistik, tycks redaktörer och journalister fortfarande ansluta sig till et ideal om dokumentarisk representation. Som bildchefen Joakim Ståhl säger har SvD fortfarande ett ideal om att tidningen ska representera verkligheten. Trots detta var soffbilden både planerad och iscensatt och efterbearbetades mer än vad som är vanligt för nyhetsbilder. Bildredaktören Jessica Olofsson är mycket medveten om detta, men tycks ändå avvisa att bilden är arrangerad när hon säger: "För mig handlar det inte om planerad journalistik utan om möjligheten att ta en bild." Här som i intervjuerna över lag ser vi en tendens till ambivalens mellan å ena sidan pressens identifikation med den dokumentariska traditionen, och å andra sidan en ökande benägenhet att skapa journalistik genom planerad produktion.

Soffbilden är ett tydligt exempel på det som Daniel Boorstin beskriver som pseudohändelser: Den är planerad av tidningens journalister, men kommer till i samarbete med källor som har intresse av uppmärksamhet. Bilden är både en konstruktion och en beskrivning av det politiska läget i Sverige inför valet 2012 . Den utgår från det faktum att det är ett valår, samtidigt som den etablerar den konkreta händelsen med de två laguppställningar som visar upp sig inför det politiska spel som ska komma att föras på den spelplan som i det moderna samhället är den viktigaste för politiken - de stora medierna (Strömbäck 2009).

Även om tidningen har planerat fotosessionen och trots att bilden är förberedd och iscensatt, blir bildens mening, betydelse och funktion kontinuerligt om- och återförhandlad, ny 
mening tillskrivs den och det uppstår nya och överraskande sätt att använda och betrakta bilden på. Svenska Dagbladet ville att bilden skulle betraktas såsom historisk, att den skulle bli en "ikonbild". Men bilden fick ett eget liv och en annan innebörd när debatten om Mona Sahlins väska bröt ut. Detaljen med väskan visar att det inte är så enkelt att bestämma över en bilds betydelse eller att avgränsa, vad den ska representera.

Samtidigt visar väskdebatten att spänningen och ambivalensen mellan det arrangerade och det spontana finns i såväl representationen som receptionen av politiker. På förstasidan bryter det arrangerade fotografiet med den dominerande tendensen att avbilda politiker som enstaka individer och visar i stället upp dem i den officiella rollen som partiledare och politiker. Men i uppslaget inne i tidningen och i websidans fotoserie får läsaren en backstage-presentation där politikerna mer får betraktas som individer som handlar autentiskt och spontant. Och med väskdebatten ändrades det dominerande perspektivet på bilden från illustration av en ny (historisk) blockpolitik till att handla om politikers personliga konsumtion.

Frågan är om "soffbilden" går till historien som "väskbilden" eller om den blir den symboliska bilden av det politiska landskapet i Sverige inför valet 2010. Om bilden blir ikon för valet 2010 är för tidigt att avgöra. Den har snabbt blivit en historisk bild i och med att alla de fyra partiledarna i det förlorande vänsterblocket har avgått två år efter valet, och den rödgröna koalitionen har dessutom upplösts som ett samlat politiskt block. Bilden fick relativt stor spridning och den symboliska betydelsen i bilden är tydlig. Men den blev inte Årets bild 2010 - det blev i stället bilden på den döda bombmannen på Drottninggatan i Stockholm december 2010.

Det är ganska få bilder som blir "ikoniska”. Analysen av soffabilden och vad som hände efter dess publicering visar att den inte uppfyller alla de kriterier som Hariman och Lucaites (2007) ställer för vad som blir en ikonisk bild. Den är visserligen väl igenkänd och fick en relativt stor spridning, den visar också en historiskt viktig situation. Men bildens betydelse försköts och de känslor som aktiveras runt ikoniska bilder kom att mer handla om Mona Sahlins handväska, än om den politiska striden mellan 
de två blocken. På det sättet kan bilden ses som typisk för stora delar av valbevakningen: En analys av fotografierna av partiledarna den sista månaden före valet i de fyra stora stockholmstidningarna visar att s-ledaren Mona Sahlin beskrevs övervägande negativt i bilder, särskilt i den liberala kvällstidningen Expressen (Heppling 2011).

Men oavsett hur "soffbildens" fortsatta öde kommer att bli, utgör den ett tydligt exempel på centrala spänningar och ambivalenser i såväl pressens egenuppfattning som i samtidens uppfattning och representation av politiker.

\section{LITTERATUR}

Asp, K. (red) (2007) Den svenska journalistkåren. Göteborg; JMG-Göteborgs universitet

Barthes, R. (1982 [1980]) Camera Lucida. London: Vintage.

Barthes, R. (1980 [1964]. "Billedets retorik”, in. Fausing, B. og Larsen, P. Visuel kommunikation, bd. 1. København: Medusa.

Becker, Karin (1996) När snön kom, ur Becker m fl: Medierummet. Stockholm; Carlssons förlag

Becker, K. (2000) "Visualizing events on the front page', in Becker, K., Ekecrantz, J., \& Olsson, T. (eds.) Picturing politics. Visual and textualformations of modernity in the Swedish press. Stockholm: JMK, Stockholms Universitet.

Becker, K. Ekecrantz, J. \& Olsson. T. (red) Picturing politics. Visual and textual formations of modernity in the Swedish press, Skriftserien 2000:1. Stockholm: Journalistik, medier och kommunikation (JMK), Stockholms universitet.

Boorstin, D. (1992 [1961]) The image. A guide to pseudo-events in America. New York: Vintage books.

Edwardsson, Å.; Anderasson, K.; Andersson-Ek, P. (1994) Göra tidning. Stockholm; Ordfronts förlag

Ekström, M. (2006) Politiken i mediesamhället: om nyhetsintervjuer och fotojournalistik. Malmö: Liber.

Forsell, J. (2002) Lennart Nilsson - hans livs bilder. Stockholm; Bonniers förlag

Gynnild, A. (1990) Avisene fangar blikket. Analyse av framsider i 1970 og 1987. Oslo: Samlaget.

Hariman, R. \& Lucaites, J. L. (2007) No Caption Needed. Iconic Photo- 
graphs, Public Culture, and Liberal Democracy. Chicago and London: University of Chicago Press.

Hariman, R. \& Lucaites, J. L. (2006) 'Liberal Representation and Global Order. The Iconic Photograph from Tianamen Square', in Prelli, L.J. (ed.) Rhetorics of Display. South Carolina: University of South Carolina.

Heppling, Linnea (2011) Parti(ska) bilder: En kvantitativ studie av pressens bilder på partiledarna under valrörelsen 2010. Södertörns högskola; magisteruppsats i journalistik

Hultén, L. (1990) Reportaget som kom av sig. Stockholm; JMK-Stockholms universitet.

Hjeltnes, G. (ed.) (2010) Imperiet vakler 1945-2010. Bind 3 i H.F. Dahl (ed.) Norsk pressehistorie 1660-2010.

Jantøy, Ann Iren (2011) 'Bildet av politikk'. Norsk medietidsskrift 3 (18), 241-262.

Kjeldsen, J.E. (2002). Visuel retorik. Dr. avhandling. Bergen: Universitetet i Bergen.

Kjeldsen, J.E. (2006) Retorik i dag. Introduktion till modern retorikteori. Stockholm: Studentlitteratur.

Kjeldsen, J.E. (2009) ”Billeders retorik”, in Roer, H. \& Lund Klujeff, M. Retorikkens aktualitet. Grundbog i retorisk kritik. København: Hans Reitzels forlag.

Kjeldsen, J.E. (2011) 'Formulars of Prize-winning Press Photos'. Paper præsenteret ved konferencen Rhetoric in Society III. January 26-28, 2011. Antwerpen

Lien, S. (2008) 'Anonym: Klasse 9A, 2007-2008', in Larsen, P. \& Lien S. Kunsten å lese bilder. Oslo: Spartacus.

Mitchell, W.J.T (1986) Iconology. Image, text, ideology. Chicago: University of Chicago Press

Meyrowitz, J. (1985) No sense of place. Oxford: Oxford University Press

Nygren, G. (2008) Nyhetsfabriken. Lund; Studentlitteratur

Nygren, G. och Zuiderveld, M. (2011) En himla massa kanaler - flerkanapublicering i svenska medieföretag. Göteborg: Nordicom

Olsson, T. (2000) ‘Den politiska föreställningen', in Karin Becker, Jan Ekecrantz \& Tom Olsson (eds.) Picturing politics. Visual and textual formations of modernity in the Swedish press, Skriftserien 2000:1, Journalistik, medier och kommunikation (JMK), Stockholms universitet.

Pedersen, F. (2001) Fotojournalisten. Praktisk fotojournalistik. Kristiansand: IJ-forlaget. 
Schudson, Michael (2005) Four Approaches to the Sociology of News, ur Curran\& Gurevitch(ed): Mass Media and Society, 4th edition, London; Hodder Arnold

Sivertsen, E. (1987) Det spissformulerte pressebildet. Arbeidsrapport nr. 3. Bergen: Institutt for massekommunikasjon, Universitetet i Bergen. Sivertsen, E. (1991) Avisfotografiet - en truet autoritet. Fotojournalistikk i dagspressen. En historisk introduksjon. Rapport nr. 11. Bergen: Institutt for massekommunikasjon, Universitetet i Bergen.

Sivertsen, E. (2006) 'Sceneskifter og linseskifter'. Norsk medietidsskrift 13(4): 339-361.

Sjöström, Sara (2011) 'Antalet - och andelen - specialreportrar minskar.' Ur Engblom, Larsåke m fl: Specialreportern - framväxt, funktion, framtid. Stockholm: Institutet för mediestudier.

Sternvik, J. (2007) I krympt kostym. Göteborg: JMG Göteborgs universitet Tuchman, Gaye (2002) The production of news, ur Bruhn Jensen, Klaus (ed) A Handbook of Media and Communication Research. London and New York; Routhledge

\section{ARTIKLAR}

Svenska Dagbladet 20110321: Martin Jönsson: Nät med nuets nerv.

\section{NOTER}

1 Pedersen (2001: 36) skilljer mellan informativ arrangering och arrangerad illustration. Den förstnämnda ska ge läsaren en kännbar information om något, den andra ska enbart illustrera och tematisera.

2 Se Sivertsen (1987). I Norge blev tydligt arrangerade och iscensatta bilder mycket vanliga på 70 - och 80 -talet. Det kunde t ex vara en finansminister som "pressar" statsbudgeten i en syltpress. Denna typ av bilder försvann i stort sett från tidningarna runt 1990 (Hjeltnes 2010: 305, 307 f.). Se også Sivertsen (1991: 55ff.) samt (2006: 342 ff.).

3 RAW-filer med alla exponeringar från ett uppdrag sparas som original i hårddiskar hos fotograferna. Det innebär att de i efterhand kan gå tillbaka och göra om bearbetningen av redan publicerade bilder och plocka fram andra bilder som inte publiceras vid det första tillfället.

4 Väskan kan betraktas som en typ av offentligt punktum, enligt Roland Barthes (1982) definition av punktum som "this element which rises from the scene, shoots out of it like an arrow, and pierces me" (1982: 26). Punktum är en detalj som "attracts or disstresses me" (1982: 49). Det är en detalj som stör eller bryter med en ordinarie eller domine- 
rande tolkning av ett fotografi, som t.ex. att läsa soffbilden som en bild av två block.

5 http://www.aftonbladet.se/nyheter/article6469796.ab

6 http://www.aftonbladet.se/nyheter/article6469814.ab

7 http://www.expressen.se/Nyheter/1.1853696/har-poserar-mona-sahlin-med-6-000-kronorshandvaska

8 http://www.newsmill.se/artikel/2010/01/22/mona-sahlins-v-ska-rett-hot-mot-socialdemokratin

9 T.ex. 1) http://divage.wordpress.com/2010/01/23/en-bild-sagersa-mycket-mer/, 2) http://parnassen.wordpress.com/2010/01/22/ rovarbandet-pa-arets-bild-lamnar-plats-i-mitten-at-jimmy-akesson/, 3) http://www.newsmill.se/artikel/2010/01/22/reinfeldtsklocka-13-g-nger-dyrare-n-sahlins-skor 